\title{
Anxiety enhances pain in a model of osteoarthritis and is associated with altered endogenous opioid function and reduced opioid analgesia
}

Amanda Lillywhite ${ }^{a, b}$, Stephen G. Woodhams ${ }^{a, b}$, Sara V. Gonçalves ${ }^{a, b}$, David J.G. Watson ${ }^{b}$, Li Li, ${ }^{a, b}$, James J. Burston $^{\mathrm{a}, \mathrm{b}}$, Peter R.W. Gowler ${ }^{\mathrm{a}, \mathrm{b}}$, Meritxell Canals ${ }^{\mathrm{b}, \mathrm{c}}$, David A. Walsh ${ }^{\mathrm{a}, \mathrm{d}, \mathrm{e}}$, Gareth J. Hathway ${ }^{\mathrm{a}, \mathrm{b}, \mathrm{e}}$, Victoria Chapman ${ }^{a, b, e, *}$

\begin{abstract}
Introduction: Negative affect, including anxiety and depression, is prevalent in chronic pain states such as osteoarthritis (OA) and associated with greater use of opioid analgesics, potentially contributing to present and future opioid crises.

Objectives: We tested the hypothesis that the interaction between anxiety, chronic pain, and opioid use results from altered endogenous opioid function.

Methods: A genetic model of negative affect, the Wistar-Kyoto (WKY) rat, was combined with intra-articular injection of monosodium iodoacetate (MIA; $1 \mathrm{mg}$ ) to mimic clinical presentation. Effects of systemic morphine $\left(0.5-3.5 \mathrm{mg} \cdot \mathrm{kg}^{-1}\right)$ on pain behaviour and spinal nociceptive neuronal activity were compared in WKY and normo-anxiety Wistar rats 3 weeks after MIA injection. Endogenous opioid function was probed by the blockade of opioid receptors $\left(0.1-1 \mathrm{mg} \cdot \mathrm{kg}^{-1}\right.$ systemic naloxone), quantification of plasma $\beta$-endorphin, and expression and phosphorylation of spinal mu-opioid receptor (MOR).

Results: Monosodium iodoacetate-treated WKY rats had enhanced OA-like pain, blunted morphine-induced analgesia, and greater mechanical hypersensitivity following systemic naloxone, compared with Wistar rats, and elevated plasma $\beta$-endorphin levels compared with saline-treated WKY controls. Increased MOR phosphorylation at the master site (serine residue 375) in the spinal cord dorsal horn of WKY rats with OA-like pain $(P=0.0312)$ indicated greater MOR desensitization.

Conclusions: Reduced clinical analgesic efficacy of morphine was recapitulated in a model of high anxiety and OA-like pain, in which endogenous opioid tone was altered, and MOR function attenuated, in the absence of previous exogenous opioid ligand exposure. These findings shed new light on the mechanisms underlying the increased opioid analgesic use in high anxiety patients with chronic pain.
\end{abstract}

Keywords: Anxiety, Arthritis, Pain, Opioids, Animal models

\section{Introduction}

Chronic pain is a major clinical problem with limited treatment options. Since the 1990s, clinical use of opioids shifted from managing acute pain and pain in terminally ill patients, to wide- spread prescribing ${ }^{19}$ for long-term pain conditions, despite limited usefulness in most people. 6,17 Opioid drugs, such as morphine, predominantly produce their effects through $\mu$-opioid receptors (MOR) at key sites in the spinal cord and brain. ${ }^{39}$ The effects of chronic pain states on endogenous opioid function

Sponsorships or competing interests that may be relevant to content are disclosed at the end of this article.

A. Lillywhite and S.G. Woodhams contributed equally to this work.

a Pain Centre Versus Arthritis, University of Nottingham, Medical School, Queen's Medical Centre, Nottingham, United Kingdom, ' School of Life Sciences, Medical School, Queen's Medical Centre, Nottingham, United Kingdom, ${ }^{\circ}$ Centre of Membrane Proteins and Receptors, Universities of Birmingham and Nottingham, Midlands, United Kingdom, ${ }^{d}$ School of Medicine, University of Nottingham, Nottingham, United Kingdom, ${ }^{e}$ NIHR Nottingham Biomedical Research Centre, University of Nottingham, Nottingham, United Kingdom

${ }^{*}$ Corresponding author. Address: Pain Centre Versus Arthritis, NIHR Nottingham Biomedical Research Centre, School of Life Sciences, Queen's Medical Centre, University of Nottingham, Nottingham NG7 2UH, United Kingdom. Tel.: +44 11582 30136. E-mail address: victoria.chapman@nottingham.ac.uk (V. Chapman).

Supplemental digital content is available for this article. Direct URL citations appear in the printed text and are provided in the HTML and PDF versions of this article on the journal's Web site (www.painrpts.com).

Copyright ( 2021 The Author(s). Published by Wolters Kluwer Health, Inc. on behalf of The International Association for the Study of Pain. This is an open access article distributed under the Creative Commons Attribution License 4.0 (CCBY), which permits unrestricted use, distribution, and reproduction in any medium, provided the original work is properly cited.

PR9 6 (2021) e956

http://dx.doi.org/10.1097/PR9.0000000000000956 
include increased release of endogenous opioid peptides, such as $\beta$-endorphin, alterations in MOR function, and lower analgesic responsiveness to morphine. ${ }^{12,45}$

Osteoarthritis $(\mathrm{OA})$ is the fastest growing cause of chronic pain worldwide, ${ }^{25,57}$ underpinned by both nociceptive and neuropathic mechanisms ${ }^{26,44}$ and central sensitization in $\sim 20 \%$ of people with OA pain. ${ }^{3,51}$ Despite high rates of opioid-prescribing for OA pain, ${ }^{10,53}$ they have no superior effect over nonopioid treatments over 12 months, ${ }^{33}$ and long-term opioid use is associated with increased risk of adverse events. ${ }^{10}$

Negative affect is associated with exacerbated chronic pain ${ }^{20}$ and is common in people with $\mathrm{OA},{ }^{5,8}$ and complex relationships between endogenous opioid function and depressive symptoms and trait anxiety have been reported. ${ }^{14}$ Negative affect is associated with the greater use of opioid analgesics in people with $\mathrm{OA}^{8,41,56}$ We hypothesised that the interaction between high anxiety, chronic pain, and increased opioid use in people may result from altered endogenous opioid function, which could be tested in a clinically relevant animal model.

Rodent models and molecular and pharmacological studies of opioid receptor function have advanced knowledge of pain mechanisms and opioid-induced analgesia. ${ }^{42,43}$ Inbred Wistar Kyoto (WKY) rats are an experimental model of anxiety-like behaviour. ${ }^{38}$ We reported increased magnitude and spread of pain behaviour in a model of OA pain in WKY rats, ${ }^{15}$ replicating the clinical association between anxiety and exacerbated $O A$ pain. In this article, we measured opiate-mediated analgesia in a clinically relevant model of OA-like pain in WKY rats and normo-anxiety Wistar rats. Effects of morphine on spinal cord neuronal excitability and antagonist-mediated blockade of opioid receptors were used to probe endogenous opioid system function in this model. Measurements of plasma levels of $\beta$-endorphin and spinal cord levels of MOR protein and MOR receptor phosphorylation at serine residue 375 (P-ser-375), which is required for opioid-mediated desensitization, ${ }^{50}$ provided important new mechanistic insights.

\section{Materials \& methods}

\subsection{Experimental animals}

Studies were conducted in accordance with UK Home Office Animals (Scientific Procedures) Act (1986) and ARRIVE guidelines. ${ }^{31} 211$ male rats were used: Wistar $n=101$ (Charles River, Margate, United Kingdom) and Wistar Kyoto $n=110$ (WKY; Envigo, Bicester, United Kingdom). The relationship between anxiety and clinical prescription opioid use is stronger in males than females ${ }^{47}$; therefore, this study was restricted to male rats, although we recognise this as a limitation. Wistar rats are the most genetically similar control strain to WKY. Rats were group housed by strain, 4 per cage in a specific pathogen-free environment with a 12-hour light or dark cycle and ad libitum access to food and water. Treatments were assigned randomly, with experimenters blinded throughout the study. 17 rats were excluded from the study (8.1\%; see Supplemental Table 1 for further details, available at http://links.Iww.com/PR9/A130).

\subsection{Induction of the monosodium iodoacetate model of osteoarthritis pain}

Rats received a single intra-articular injection, randomly assigned to either $1 \mathrm{mg} / 50 \mu \mathrm{L}$ MIA in $0.9 \%$ saline (Wistar $n=54$ and WKY $n$ $=51$ ) or $50 \mu \mathrm{L} 0.9 \%$ saline (Wistar $n=47$ and WKY $n=47$ ), through the infrapatellar ligament into the left knee, under isoflurane anaesthesia ( $3 \%$ in $1 \mathrm{~L} \cdot \mathrm{min}^{-1} \mathrm{O} 2^{48}$ ). 12 naïve WKY animals were also used in this study (see 2.3 below). Health and welfare checks were performed immediately after anaesthetic recovery, daily for 3 days, and weekly thereafter. Pain behaviour was assessed twice weekly from D3 to 21.

\subsection{Behavioural testing}

Pain behaviour was assessed by weight-bearing (WB) asymmetry using an incapacitance tester ${ }^{11}$ (Linton Instrumentation, Diss, United Kingdom). Weight-bearing asymmetry was calculated as [ipsilateral g/(ipsilateral g + contralateral g)]. Mechanical hind paw withdrawal thresholds (PWTs) were determined by von Frey hair $(\mathrm{vFH})$ monofilaments using the up-down method. ${ }^{16}$ As the intervals between successive $\mathrm{vFH}$ are logarithmic, ${ }^{40}$ PWTs are reported as log $\mathrm{vFH}$ values to avoid biasing statistical comparisons. To enable pooling of experimental studies (see Supplemental Table 2, available at http://links.lww.com/PR9/A130) and preserve the interval nature of the $\mathrm{VFH}$ scale, PWTs were converted to change in the number of $\mathrm{vFH}$ from baseline for Figure 1.

To measure anxiety-like behaviour, the total time spent in closed vs open arms in the elevated plus maze $\left(\mathrm{EPM}^{58}\right)$ over a period of 10 minutes was quantified using EthoVision software (Noldus Information Technology, Netherlands).

To measure the locomotor activity, the number of beam breaks over 30 minutes in activity boxes (Photobeam Activity System; San Diego Instruments) was assessed at baseline and 19 to 21 days after model induction. ${ }^{46}$ To rule out effects of morphine on motor activity, the locomotor activity was assessed 60 to 90 minutes after the last of 3 consecutive doses of morphine $(0.5,2$, and $3.5 \mathrm{mg} \cdot \mathrm{kg} \cdot \mathrm{mL}^{-1}$, s.c.; $\left.\mathrm{n}=6\right)$ or saline $(50 \mu \mathrm{L} ; \mathrm{n}=6)$ in a separate cohort of WKY rats.

\subsection{Pharmacological interventions}

\subsubsection{Systemic morphine or naloxone or CTAP behavioural study}

To assess differences in opioid sensitivity or alterations in endogenous opioidergic tone, behavioural nociceptive responses after consecutive subcutaneous (s.c.) doses of morphine, the nonselective opioid receptor antagonist naloxone, and the MOR-selective antagonist D-Phe-Cys-Tyr-D-Trp-Arg-Thr-Pen-Thr-NH2 (CTAP $\left.{ }^{1}\right)$ or vehicle ( $0.9 \%$ saline) were determined in separate groups of Wistar and WKY rats 21 days after model induction. Pain behaviour was assessed in MIA-treated or saline-treated rats predrug and then after the following treatments: study $1-$ morphine $(0.5,2$, and 3.5 $\mathrm{mg} \cdot \mathrm{kg} \cdot \mathrm{mL}^{-1}$, s.c.; Wistar/MIA $n=10$, WKY/MIA $n=10$ ) or vehicle Wistar/saline $n=8$ and WKY/saline $n=8)$; study 2 - naloxone (0.1, 0.3 , and $1 \mathrm{mg} \cdot \mathrm{kg} \cdot \mathrm{mL}^{-1}$, s.c.; Wistar/saline $\mathrm{n}=12$, Wistar $/ \mathrm{MIA} \mathrm{n}=$ 12 , WKY/saline $n=10$, and WKY/MIA $n=11)$; study 3 - CTAP $(0.1$, 0.3 , and $1 \mathrm{mg} \cdot \mathrm{kg}^{-1} \cdot \mathrm{mL}^{-1}$,i.p.; Wistar/MIA $n=10$ and WKY/MIA $n=$ 10). Drug treatments were given at 60 minute intervals, and pain behaviour assessed at 15, 30, and 60 minutes after each dose (study 1 and 2), or 30 minutes only after each dose (study 3) (based on previous published literature ${ }^{9,37}$ ). \% morphine analgesia was calculated for weight-bearing, with $100 \%$ analgesia equalling total normalisation of weight-bearing asymmetry. For effects of drug treatments on PWT, data are reported as logPWT values.

\subsubsection{In vivo spinal electrophysiology}

Responses of deep dorsal horn wide dynamic range (WDR) neurons to hind paw stimulation were recorded 21 days after 

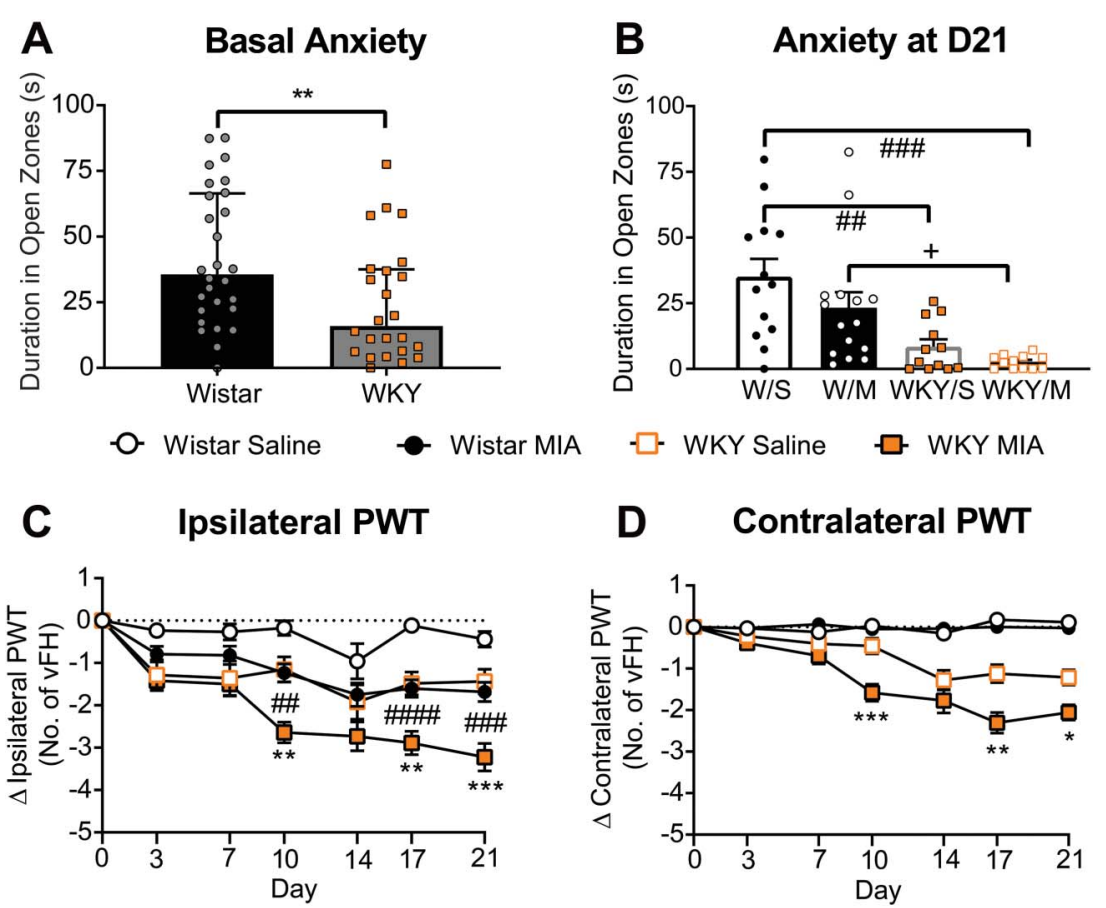

D Contralateral PWT
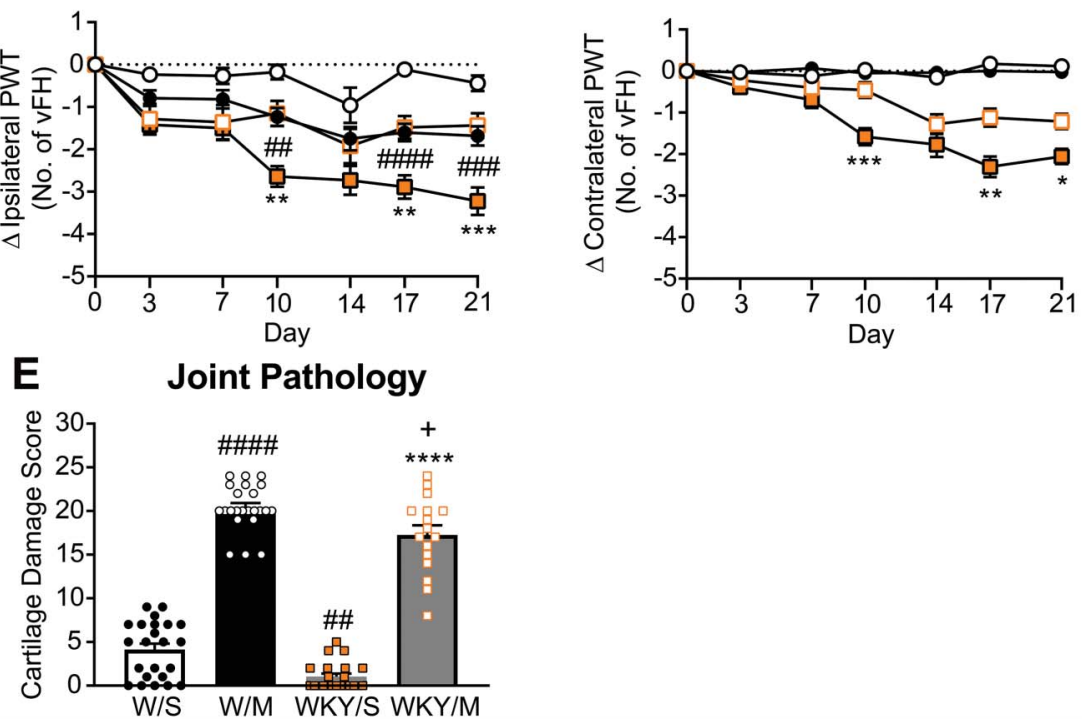

Figure 1. Anxiety-like phenotype and exacerbated OA-like pain in the WKY-MIA model. At baseline, WKY rats spent significantly less time in the open arms of the elevated plus maze (A). Bars indicate median values, and error bars represent IQR. ${ }^{\star \star} P<0.01$ vs Wistar rats, one-tailed Mann-Whitney $U$ test (Supplemental Table 3, available at http://links.Iww.com/PR9/A130). Three weeks after model induction, there was no significant effect of treatment on duration spent in the open arms of the elevated plus maze (B). MIA-treated and saline-treated WKY rats had a significant anxiety-like phenotype, compared with their respective Wistar groups. Data represent total duration in the open arms for each 10 minutes trial. Individual data points are shown, and bars represent the mean and SEM. \#\#P $=0.0032$, \#\#\#P $<0.003$ vs Wistar/saline, $+P=0.0246$ vs Wistar/MIA, 2-way ANOVA with the Tukey multiple comparison post hoc test (Supplemental Table 6, available at http://links.Iww.com/PR9/A130). MIA-treated rats had lowered ipsilateral PWT in WKY and Wistar rats (C). Contralateral PWTs were unaltered in MIA-injected or saline-injected Wistar rats but significantly lowered in MIA-treated WKY rats (D). Data are mean \pm SEM change in $v F H$ compared with baseline, ${ }^{\star} P<0.05$, ${ }^{\star \star} P<$ $0.01,{ }^{\star \star \star} P<0.001$ WKY/MIA vs WKY/saline, \#\#P $<0.01$, \#\#\#P $<0.001$, \#\#\#\#P<0.0001 Wistar/MIA vs Wistar/saline, mixed-effects model analysis with the Tukey multiple comparison post hoc test (Supplemental Table 7, available at http://links.Iww.com/PR9/A130). Macroscopic assessment of cartilage damage in ipsilateral knee joints in MIA-injected WKY and Wistar rats. Little or no cartilage damage was observed in saline-injected rats (E). Data represent the summed scores for each of the 5 individual joint compartments (0-5, max score 25). Individual data points are shown, and bars represent the mean and SEM. \#\#P = 0.0054 , \#\#\#\#P<0.0001 vs Wistar/saline, ${ }^{\star \star \star \star} P<0.0001$ vs WKY/saline, $+P=0.0123$ vs Wistar/MIA, 2 -way ANOVA with the Tukey multiple comparison post hoc test (Supplemental Table 6, available at http://links.Iww.com/PR9/A130). ANOVA, analysis of variance; MIA, monosodium iodoacetate; OA, osteoarthritis; PWTs, paw withdrawal thresholds; vFH, von Frey hair; WKY, Wistar Kyoto.

model induction (Wistar/saline $n=10$, Wistar/MIA $n=15, \mathrm{WKY} /$ saline $n=12$, and WKY/MIA $n=12$ ) as previously described ${ }^{55}$ (see Supplementary Methods, available at http://links.Iww.com/ PR9/A130). WDR neuronal responses to mechanical hind paw stimulation with $8,10,15$, and $26 \mathrm{~g} \mathrm{vFH}$ (10 seconds application and 10 seconds interstimulus interval) were recorded at 10 minute intervals to establish baseline responses and then every 10 minutes after consecutive doses of morphine sulfate $(0.5,2$, and $3.5 \mathrm{mg} \cdot \mathrm{kg}^{-1}$, s.c., 60 minute intervals).

Responses of WDRs were binned according to poststimulus latency for major primary afferent fibres (A $\beta$ 0-20 ms, A $\delta$ 20-90 ms, C 90-300 ms, and post-stimulus discharge 300-800 ms). Degree of wind-up was determined as the total number of $\mathrm{C}$ fibre and poststimulus discharge spikes after a train of 16 stimuli (3x C-fibre threshold, $0.5 \mathrm{~Hz}$ ). For mechanical stimuli, average firing rates $(\mathrm{Hz})$ in response to 10 seconds stimulation with each $\mathrm{vFH}$ were recorded.
The mean maximal inhibition (MMl) was calculated as maximal \% change vs baseline for each dose of morphine and plotted by strain and treatment for each dose. For each $\mathrm{vFH}$, the area under the curve (AUC) was calculated from MMl values for each dose for each individual animal and animals grouped by strain and treatment and compared in Prism 8.

\subsection{Assessment of opioid function in ex vivo tissues}

\subsection{1. $\beta$-endorphin ELISA}

Levels of the endogenous opioid peptide $\beta$-endorphin were measured in plasma from male Wistar $(n=18)$ and WKY $(n=18)$ rats from study 3 using a commercially available enzyme-linked immunosorbent assay (ELISA) kit (Phoenix Pharmaceuticals, Burlingame, CA) according to the manufacturer's instructions 
(see Supplemental Methods, available at http://links.Iww.com/ PR9/A130).

\subsubsection{Western blotting}

Fresh spinal cord tissue was collected from WKY and Wistar rats 21 days after MIA or saline treatment (cohort 3, $n=4 /$ strain) and probed for the expression of total MOR (rabbit anti-mu-opioid receptor, Neuromics, RA10104, 1:500), P-ser375 MOR (rabbit anti-mu-opioid receptor Ser375, BIOSS-Stratech, bs-3724R, 1: 500 ), and $\beta$-actin (mouse anti- $\beta$-actin, Sigma, A5441, 1:5000) using Western blotting (see Supplemental Methods, available at http://links.lww.com/PR9/A130).

\subsection{Assessment of joint pathology}

Knee joints from each animal were fixed in 10\% neutral buffered formalin (48 hours), disarticulated, and macroscopic cartilage damage scored by a blinded experimenter by established methods. $^{28} 7 \%$ of rats were excluded due to joint pathology inconsistent with the treatment group (see Supplemental Table 1, available at http://links.Iww.com/PR9/A130).

\subsection{Statistical analyses}

Power calculations based on data from a similar previous study in this model ${ }^{15}$ were used to determine appropriate group sizes (see Supplemental Methods, available at http://links.Iww.com/PR9/ A130). Data were analysed using Prism 8 (GraphPad, La Jolla, CA). Data distributions were assessed by Shapiro-Wilk normality testing, and treated as parametric or nonparametric, as appropriate. Further statistical details are provided in Supplemental Methods (available at http://links.lww.com/PR9/A130).

\section{Results}

\subsection{Wistar Kyoto rats exhibit a basal anxiety-like phenotype and exacerbated pain behaviour in the monosodium iodoacetate model of osteoarthritis}

Wistar Kyoto rats spent significantly less time in the open arms of the elevated plus maze (EPM) when compared with Wistar rats (Fig. 1A, Supplemental Table 3, available at http://links.Iww.com/ PR9/A130). These data support a basal anxiety-like phenotype in the WKY strain. There was a significant effect of strain (Fig. 1B, Supplemental Table 6, available at http://links.Iww.com/PR9/ A130, $P<0.0001)$, but a nonsignificant effect of treatment $(P=$ 0.086) on the time spent in the open arms of the EPM, consistent with our previous work. ${ }^{15}$ Locomotor activity was comparable between strains (Supplemental Figure 1C, available at http:// links.Iww.com/PR9/A130).

WKY and Wistar rats exhibited comparable hind paw withdrawal thresholds (PWTs), and weight was borne equally on both hind paws before any intervention (Supplemental Table 2, available at http://links.Iww.com/PR9/A130). Consistent with previous work, ${ }^{15}$ ipsilateral PWT were lowered in both strains of rats (Fig. 1C), from day 10 after intra-articular injection of MIA. A significantly greater reduction in ipsilateral PWTs was observed in WKY rats, compared with Wistar rats (Supplemental Tables 2 and 6, available at http://links.lww. com/PR9/A130), with a reduction in contralateral PWTs in WKY rats alone (Fig. 1D, Supplemental Table 7, available at http://links.Iww.com/PR9/A130), consistent with the presence of central sensitization and an exacerbated OA-like pain phenotype in WKY rats. ${ }^{15}$ Rats treated with MIA exhibited weight-bearing asymmetry in both strains of rats (Supplemental Figure 1A, available at http://links.Iww.com/PR9/A130); this was less pronounced in the WKY strain, presumably because of lowered contralateral pain PWTs confounding this measure in a similar manner to models of neuropathic pain.

\subsection{Osteoarthritis-like joint pathology}

There were significant increases in cartilage damage in the MIA model in both WKY and Wistar rats (Fig. 1E, Supplemental Table 6, available at http://links.lww.com/PR9/A130). It is noteworthy that, despite the exacerbated pain phenotype, there was significantly less cartilage damage observed in WKY rats compared with Wistar rats.

\subsection{Reduced effects of systemic morphine in the Wistar Kyoto-monosodium iodoacetate model of high anxiety and osteoarthritis-like pain behaviour}

Systemic administration of morphine $\left(0.5,2\right.$, and $3.5 \mathrm{mg} \cdot \mathrm{kg}^{-1}$ s.c.) produced a significant, dose-related reduction in weightbearing asymmetry in Wistar rats (Fig. 2A, Supplemental Table 5, available at http://links.lww.com/PR9/A130). By contrast, only the highest dose of morphine significantly inhibited weightbearing asymmetry in MIA-treated WKY rats (Fig. 2A). Similarly, morphine had a significantly blunted inhibitory effect on lowered ipsilateral PWTs in MIA-treated WKY rats, compared with the Wistar strain (Fig. 2B, Supplemental Table 6, available at http:// links.Iww.com/PR9/A130). All 3 doses of morphine significantly restored PWT deficits in MIA-treated Wistar rats, whereas only the highest dose of morphine produced significant reversal of ipsilateral PWTs in WKY rats (Fig. 2B, Supplemental Table 6, available at http://links.Iww.com/PR9/A130). The highest dose of morphine also significantly reversed the lowered contralateral PWT evident in MIA-treated WKY rats (Fig. 2C, Supplemental Table 6, available at http://links.lww.com/PR9/A130). The assessment of locomotor activity after the dosing paradigm confirmed that the blunted effects of morphine in WKY rats were not due to morphine-induced suppression of locomotor activity in WKY rats (Supplemental Figure 2A\&B, available at http://links. Iww.com/PR9/A130).

\subsection{Evidence for altered systemic endogenous opioid signalling in Wistar Kyoto rats}

We hypothesised that the reduced inhibitory effects of morphine on pain behaviour in WKY rats may arise as a result of changes in opioid receptor function or circulating levels of endogenous opioids. The effects on pain behaviour of blocking the $\mu$-opioid receptor with the antagonist naloxone were assessed in the MIA model in both strains of rats (Fig. 3). Naloxone $\left(0.1-1 \mathrm{mg} \cdot \mathrm{kg}^{-1}\right.$ s.c.) did not alter PWTs in Wistar rats in the absence of the model of OA-like pain (intra-articular injection of saline), suggesting no overt basal endogenous opioidergic tone in these rats. However, all 3 doses of naloxone $\left(0.1-1 \mathrm{mg} \cdot \mathrm{kg}^{-1}\right)$ significantly lowered ipsilateral PWTs in MIA-treated Wistar rats, suggesting the presence of endogenous opioid tone after the induction of the model of OA pain in this strain of rats. In WKY rats, naloxone $\left(0.1-1 \mathrm{mg} \cdot \mathrm{kg}^{-1}\right)$ produced a significant bilateral lowering of PWTs (Fig. 3A-D, Supplemental Table 6, available at http://links.Iww. com/PR9/A130), which was similar in both saline-treated and MIA-treated WKY rats. These effects were mirrored in animals treated with the selective MOR antagonist, CTAP (Supplemental Figures 3A\&B, available at http://links.lww.com/PR9/A130), 


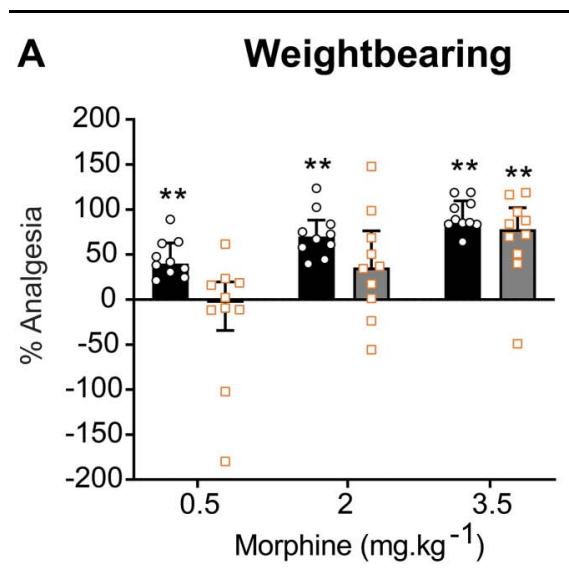

\section{B Ipsilateral PWT}

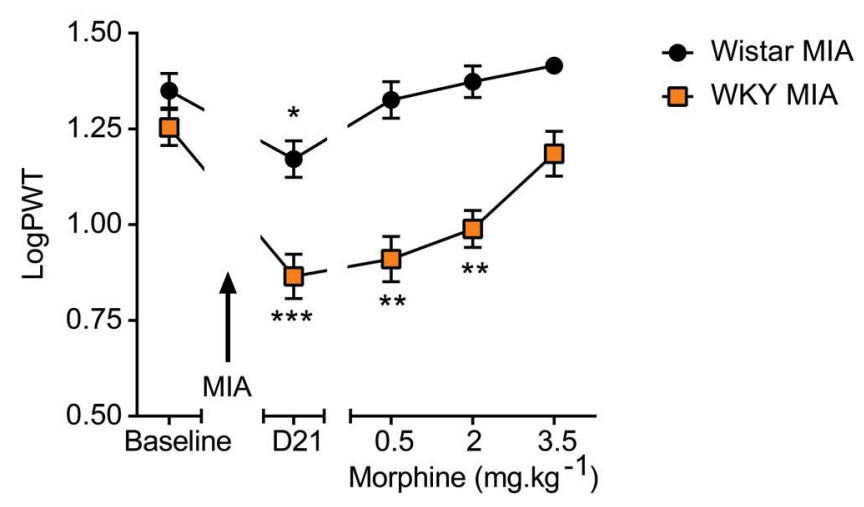

C Contralateral PWT

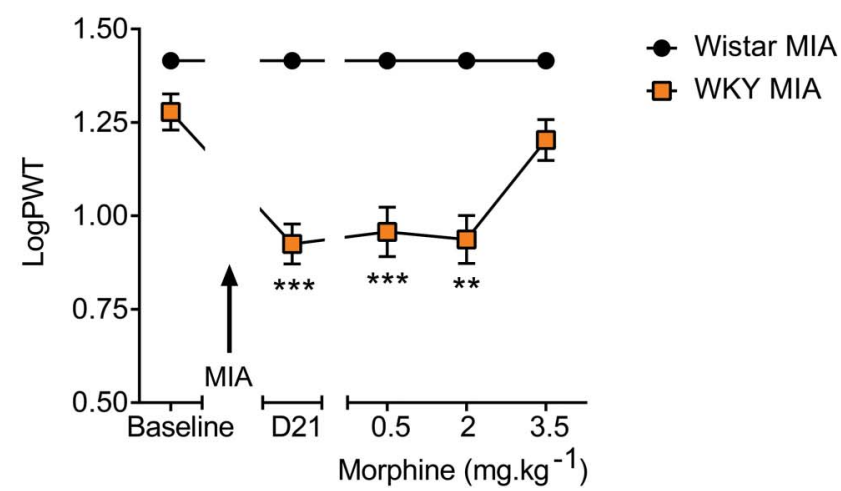

Figure 2. Reduced behavioural response to systemic morphine in the WKYMIA model of high anxiety and OA-like pain. Systemic administration of morphine produced dose-related inhibition of weight-bearing asymmetry in the MIA model in Wistar rats (A), inhibitory effects of low dose morphine were significantly attenuated in WKY rats. Data represent \% analgesia to 3 consecutive doses of systemic morphine, with abolition of weight-bearing asymmetry representing $100 \%$ analgesia ${ }^{* \star} P=0.01$, Wilcoxon signed-rank test with a hypothetical value of 0 (Supplemental Table 5, available at http:// links.Iww.com/PR9/A130). The lowest dose of morphine restored MIAinduced decreases in ipsilateral PWTs in Wistar, but not WKY, rats (B). Morphine did not significantly alter contralateral PWTs in MIA-injected Wistar rats; the highest dose of morphine reversed lowered contralateral PWTs in MIA-injected WKY rats (C). Data represent mean \pm SEM logPWT values. ${ }^{*} P<$ $0.05,{ }^{\star \star} P<0.01,{ }^{\star \star \star} P<0.001$ vs baseline, repeated measures 2 -way ANOVA with Dunnett multiple comparison post hoc testing (Supplemental Table 6, available at http://links.Iww.com/PR9/A130). ANOVA, analysis of variance; MIA, monosodium iodoacetate; OA, osteoarthritis; PWTs, paw withdrawal thresholds; vFH, von Frey hair; WKY, Wistar Kyoto. supporting an effect mediated by $\mu$-opioid receptors. These data suggest the presence of altered endogenous opioid peptides, or increased constitutive activity of MOR, in WKY rats in the absence of the OA pain model, which is not further increased in the presence of the model.

Plasma levels of $\beta$-endorphin were assayed in tail vein blood from both strains of rats collected under brief isoflurane anaesthesia. At baseline, plasma $\beta$-endorphin was significantly lower in WKY rats, compared with Wistar rats (Fig. 3E, Supplemental Table 3, available at http://links.Iww.com/PR9/ A130). At 21 days after intra-articular injection of saline, plasma levels of $\beta$ endorphin were higher in both Wistar and WKY rats compared with baseline (Fig. 3F). At 21 days after intra-articular injection of MIA in Wistar rats, plasma levels of $\beta$-endorphin were comparable with levels in saline-treated Wistar rats at this timepoint (Fig. 3F). At 21 days after intra-articular injection of MIA in WKY rats, plasma levels of $\beta$-endorphin were increased compared with levels in saline-treated WKY rats at this timepoint (Fig. 3F, Supplemental Table 4, available at http://links.Iww.com/ PR9/A130). In our hands, plasma levels of enkephalin were below the detection limits (measured by commercially available ELISA), and therefore, we cannot rule out changes in other endogenous opioids (data not shown).

\subsection{The spinal cord: a potential site of reduced morphine efficacy in this model of high anxiety and osteoarthritis pain}

To evaluate a potential locus for the altered behavioural phenotype in the WKY-MIA model, in vivo single-unit recordings of WDR neurons in the spinal cord dorsal horn were made in saline or MIA-treated rats (see Supplemental Figure 4 for sample data, available at http://links.lww.com/PR9/A130). Basal neuronal characteristics were similar across groups (see Supplemental Table 8, available at http://links.Iww.com/PR9/A130). Neuronal responses to an overtly nociceptive electrical stimulus (3x C-fibre threshold, 2ms) were significantly higher in the WKY strain and further elevated in MIA-injected rats (Fig. 4A, B, Supplemental Table 7, available at http://links.lww.com/PR9/A130, $P<$ $0.0001)$. Action potentials recorded in the $A \delta$ range were significantly elevated (3-fold) in WKY rats compared with Wistar rats (Fig. 4A, Supplemental Table 6, available at http://links.Iww. com/PR9/A130), and responses in the C-fibre latency range were significantly higher in MIA-injected WKY rats, compared with both saline-treated and MIA-treated Wistar rats (Fig. 4B, Supplemental Table 6, available at http://links.lww.com/PR9/A130). A significant effect of strain was also observed for the degree of wind-up, a proxy of central sensitization ${ }^{35}$ (Fig. 4C, Supplemental Table 6, available at http://links.Iww.com/PR9/A130 $P<$ $0.0001)$, with the highest responses evident in MIA-treated WKY rats. There were no differences in responses in the nonnoxious $A \beta$-fibre latency, post-stimulus discharge (Supplemental Figure 5A\&B, available at http://links.lww.com/PR9/ A130), or mechanically evoked responses of WDR neurons (Supplemental Figure 5C, Supplemental Table 6, available at http://links.Iww.com/PR9/A130).

In line with our behavioural data, inhibitory effects of consecutive systemic doses of morphine on evoked responses of spinal neurons were significantly blunted in MIA-treated WKY rats, compared with Wistar rats (Fig. 4D-I). The lowest dose of morphine $\left(0.5 \mathrm{mg} \cdot \mathrm{kg}^{-1}\right)$ had a similar mean maximal inhibitory effect on a range of noxious and nonnoxious mechanical 


\section{- - Wistar Saline - Wistar MIA $\square-$ WKY Saline $\square$ WKY MIA}
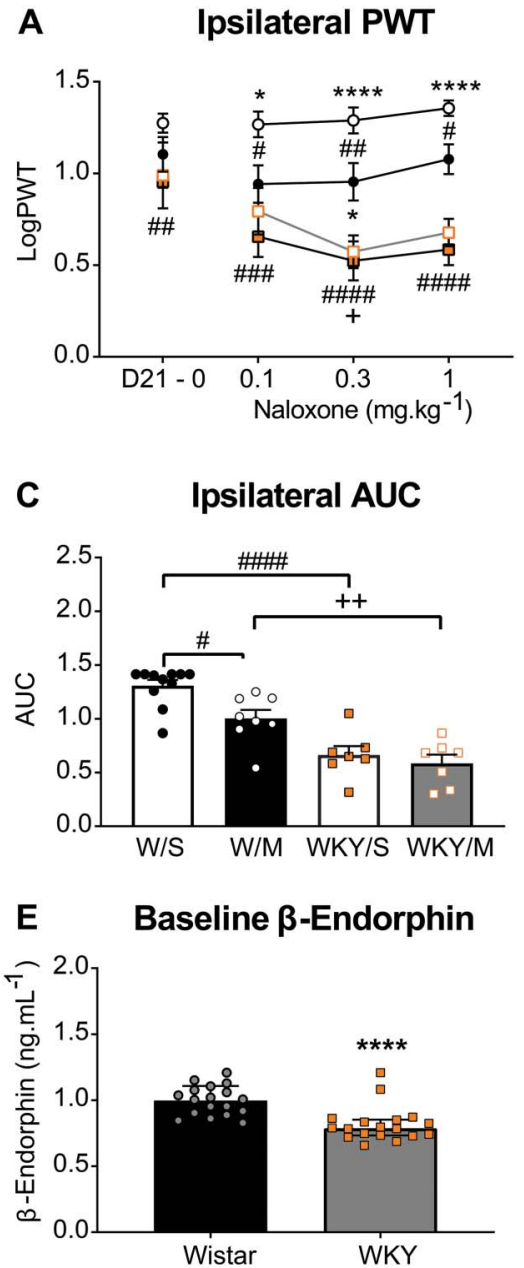

B Contralateral PWT

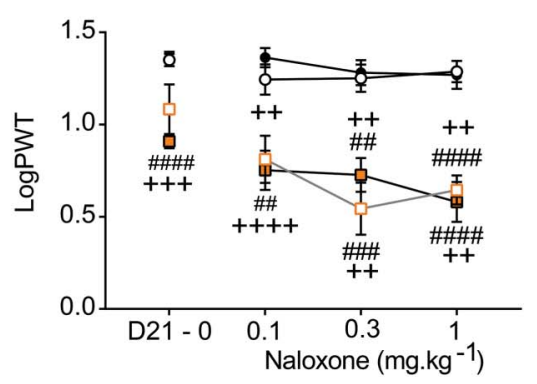

D Contralateral AUC

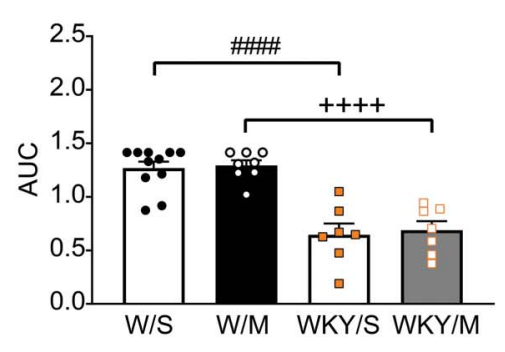

$\mathbf{F}$

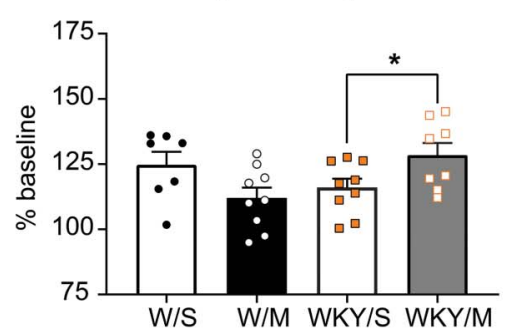

Figure 3. Altered endogenous opioid tone in rats with an anxiety-like phenotype. Systemic administration of the MOR antagonist naloxone $\left(0.1-1\right.$ mg.kg ${ }^{-1}$, s.c.) significantly lowered ipsilateral PWTs in MIA-injected, but not saline-injected, Wistar rats (A). In both saline-treated and MIA-treated WKY rats, naloxone produced a significant, dose-dependent, and bilateral lowering of PWTs (A and B). Data represent mean \pm SEM for baseline PWTs and MMI values for each consecutive

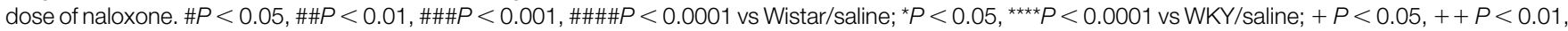
$+++P<0.001,++++P<0.0001$ vs Wistar/MIA, 2-way ANOVA with Tukey multiple comparison post hoc testing (Supplemental Table 6, available at http:// links.Iww.com/PR9/A130). LogPWTs were plotted for each dose and the AUC calculated for each individual animal via Prism. These data revealed a significantly greater effect of naloxone on ipsilateral (C) and contralateral (D) PWTs in WKY rats when compared with Wistar rats. Individual data points; bars represent mean and SEMs. \#P $<0.0167$, \#\#\#\#P<0.0001 vs Wistar/saline; $++P=0.026,++++P<0.0001$ vs Wistar/MIA, 2-way ANOVA with Tukey multiple comparison post hoc testing (Supplemental Table 6, available at http://inks.Iww.com/PR9/A130). Baseline plasma levels of $\beta$-endorphin were measured by ELISA in samples collected from naive Wistar $(n=18)$ and WKY $(n=18)$ rats $(E)$. Bars represent the mean value, error bars indicate SEM. ${ }^{* \star * \star} P=<0.0001$, unpaired $t$ test (Supplemental Table 3, available at http://links.Iww.com/PR9/A130). At 21 days after injection of MIA, plasma levels of $\beta$-endorphin were higher in WKY rats $(\mathrm{n}=9$ ) but not Wistar rats $(n=8-9)$. Bars represent the mean value, and error bars indicate SEM ${ }^{\star} P=0.044$, unpaired $t$ test (Supplemental Table 4 , available at http:// links.Iww.com/PR9/A130). ANOVA, analysis of variance; MIA, monosodium iodoacetate; MOR, $\mu$-opioid receptors; OA, osteoarthritis; PWTs, paw withdrawal thresholds; vFH, von Frey hair; WKY, Wistar Kyoto.

stimuli-evoked responses, but there was little additional inhibition after successive increased doses of morphine in the WKY-MIA rats, unlike inhibitory effects evident in Wistar-MIA rats (Fig. 4D-E, G-H, Supplemental Table 3, available at http://links.Iww. com/PR9/A130).

\subsection{Spinal $\mu$-opioid receptor function altered in the high anxiety model of osteoarthritis pain}

To explore potential changes in MOR function, we quantified spinal cord MOR expression. Western blotting revealed no significant effect of strain or treatment on total dorsal horn MOR expression (Fig. 5A, B). There was a significant increase in phosphorylation at P-ser375 in MIA-treated WKY rats compared with saline-treated WKY rats (Fig. 5C, Supplemental Table 6, available at http://links.Iww.com/PR9/A130). This was not evident in Wistar rats (Fig. 5C, Supplemental Table 6, available at http://links.Iww.com/PR9/A130). These data support an alteration in spinal MOR function in MIA-treated WKY rats, in the absence of exogenous morphine treatment.

\section{Discussion}

Clinically, people with high anxiety and chronic pain, including $\mathrm{OA}$ pain, have greater opioid consumption compared with people with comparable pain but less anxiety. ${ }^{8}$ This clinical problem was 

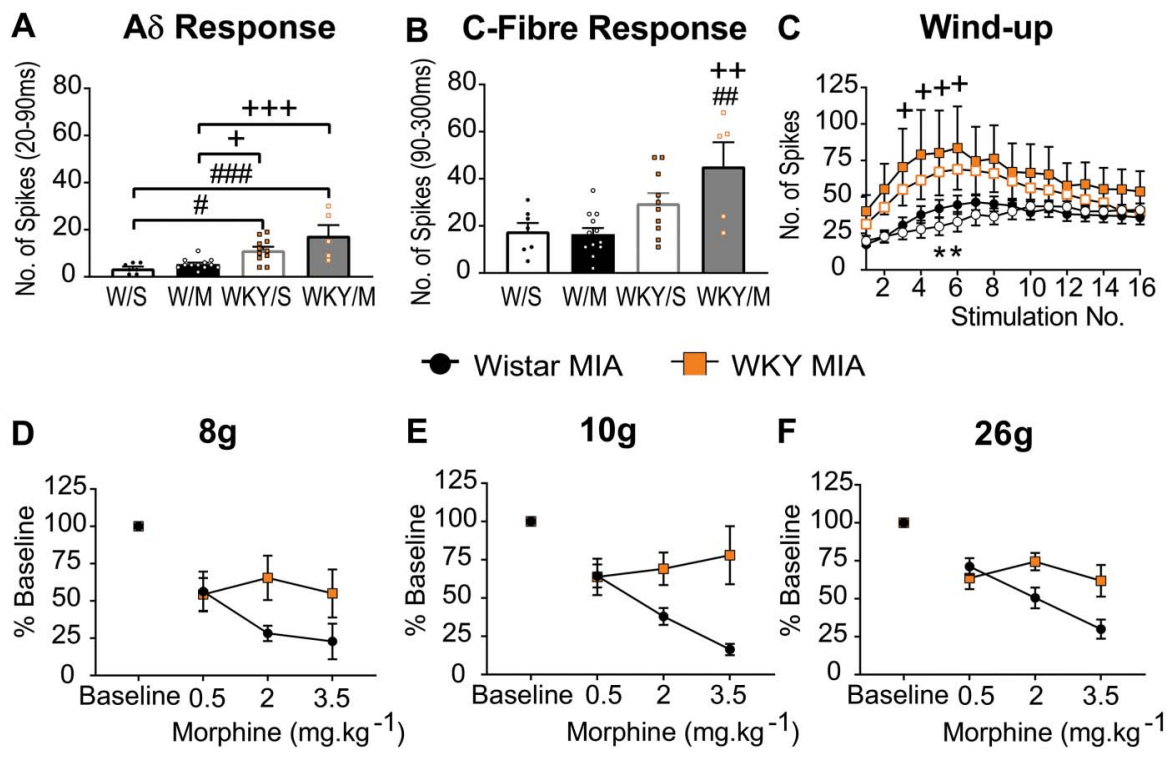

\section{WKY MIA}
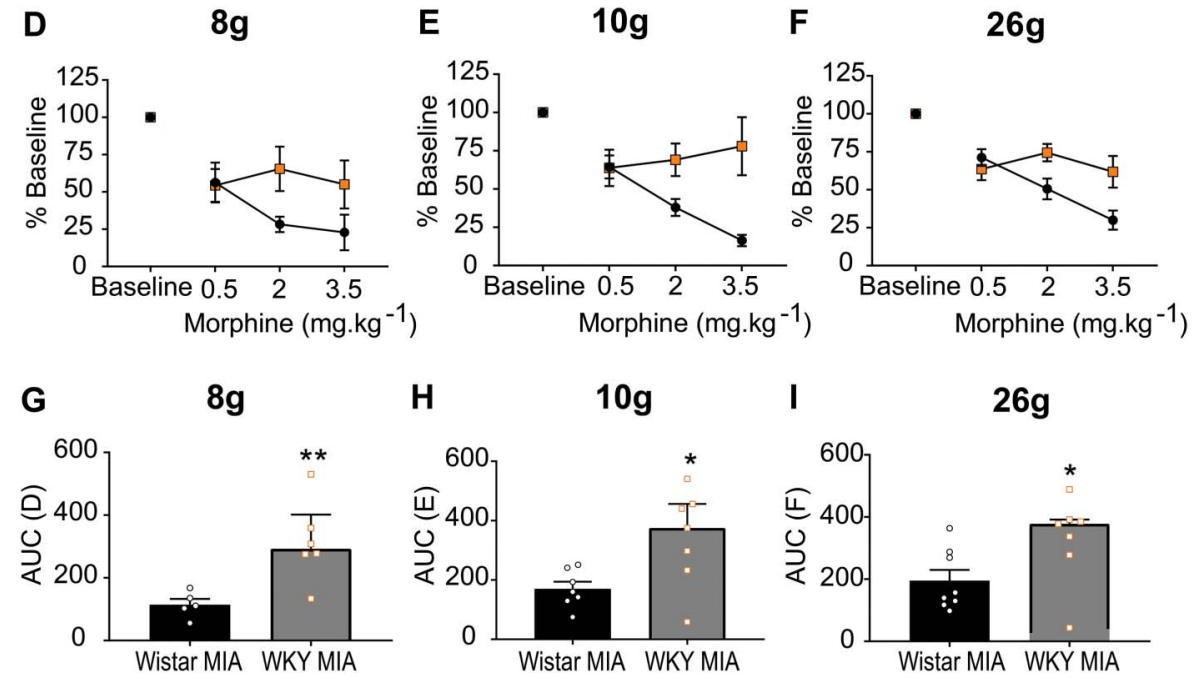

Figure 4. Enhanced excitability of spinal neurons and reduced efficacy of systemic morphine in the WKY-MIA model. In vivo electrophysiological recordings of responses of WDR neurons in the deep dorsal horn. The number of action potentials after a noxious electrical stimulus at 3x C-fibre latency was binned according to latency. Responses in the $A \delta$-fibre latency range were higher in WKY rats compared with Wistar rats (A). Responses in the C-fibre latency range were higher in WKY rats $(B)$ and significantly increased in MIA-treated WKY rats. Data are the average number of action potentials recorded within each poststimulus latency band, with individual data points shown; bars represent the median values and IQR. $\# P=0.0144, \# \# P=0.0067, \# \# \#=0.0002 \mathrm{vs}$ Wistar/saline, $+P=0.0365$, $++P=0.0017,+++P=0.0004$ vs Wistar/MIA, 2-way ANOVA with the Tukey post hoc multiple comparisons test (Supplemental Table 6, available at http:// links.Iww.com/PR9/A130). Wind-up responses of WDR neurons was greater in WKY rats (C). The number of action potentials recorded in the 90 to $800 \mathrm{~ms}$ poststimulus ( $\mathrm{C}$ fibre to post-stimulus discharge latency range) was significantly higher in saline-injected WKY rats (stimuli 5 and 6) and MIA-injected WKY rats (stimuli 3-6), compared with Wistar rats. Data represent mean \pm SEM number of action potentials. ${ }^{*} P<0.05$ vs WKY/saline, $+P<0.05$ vs Wistar/MIA, 2 -way ANOVA with the Tukey post hoc multiple comparisons test (Supplemental Table 6, available at http://links.Iww.com/PR9/A130). There was a blunted effect of 2 and $3.5 \mathrm{mg} \cdot \mathrm{kg}^{-1}$ morphine on mechanically evoked responses of spinal WDR neurons in MIA-injected WKY rats: $8 \mathrm{~g}-(\mathrm{D}), 10 \mathrm{~g}-(\mathrm{E})$, and $26 \mathrm{~g}$-evoked (F) vFH evoked responses of WDR neurons in MIA-injected WKY rats, which was confirmed by AUC analysis (G-I). Data represent median $\pm I Q R$, ${ }^{\star} P<0.05$, ${ }^{\star *} P<0.01$ Mann-Whitney $U$ tests (Supplemental Table 3, available at http://links.Iww.com/PR9/A130). ANOVA, analysis of variance; MIA, monosodium iodoacetate; PWTs, paw withdrawal thresholds; vFH, von Frey hair; WDR, wide dynamic range; WKY, Wistar Kyoto.

mimicked in a rodent model of high anxiety and OA-like pain; our mechanistic studies revealed multiple lines of evidence supporting altered endogenous opioid function, including increased phosphorylation at serine residue 375 of $\mathrm{MOR}$, which is required for opioid-mediated desensitization, ${ }^{50}$ in the absence of previous exposure to exogenous opioid ligand.

Systemically administered morphine produced a robust inhibition of behavioural pain responses after OA-induced joint pathology in Wistar rats, which do not normally exhibit an anxiogenic phenotype. However, in WKY rats, which have a heightened anxiety-like phenotype, the effects of morphine on OA-induced pain behaviour were significantly blunted. The lowest dose of morphine did not reverse weight-bearing asymmetry or hind paw withdrawal thresholds in MIA-treated WKY rats, despite significant inhibitory effects in the MIA-treated Wistar rats. This may reflect the greater pain behaviour in MIA-treated WKY rats; however, a similar low dose of morphine reversed far greater weight-bearing asymmetry induced by tibio-tarsal carrageenan injection. ${ }^{49}$ In our study, the highest dose of systemic morphine studied produced comparable inhibitory effects on MIA-induced pain behaviour in both strains of rats, thus reduced efficacy of opioid signalling, rather than a loss of receptors in WKY rats, is likely to explain these differences in the effects of morphine. Plasma levels of morphine after systemic administration have been shown to be equivalent in WKY and SD rats, ${ }^{23}$ and therefore, metabolism of exogenous opioids is an unlikely confounder. Reduced efficacy of morphine in WKY rats has been reported in both acute pain tests and the formalin model, ${ }^{23}$ and here, we report blunted opioid analgesia in a clinically relevant model of chronic OA pain in WKY rats. Our data are consistent with the clinical evidence that anxiety in people with joint pain is associated with the greater $^{8}$ or more prolonged ${ }^{41}$ use of prescription opioids.

To investigate the basis for the blunted analgesic efficacy of morphine in WKY rats with the model of OA pain, the effects of pharmacological blockade of MOR on pain behaviour were explored. Systemic naloxone or the MOR-selective antagonist CTAP lowered hind paw withdrawal thresholds in Wistar rats in the presence of the model of OA pain, but not in pain-free, salinetreated Wistar rats. These data are consistent with the 
A

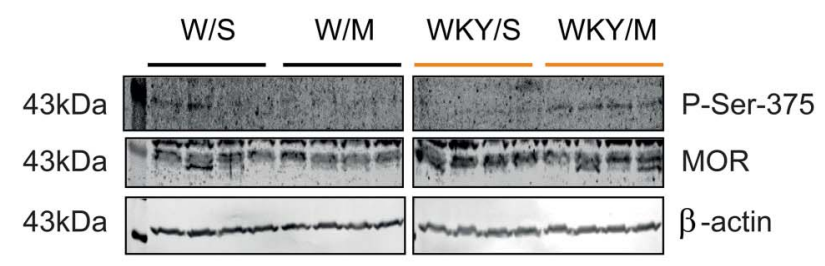

B Spinal MOR Protein
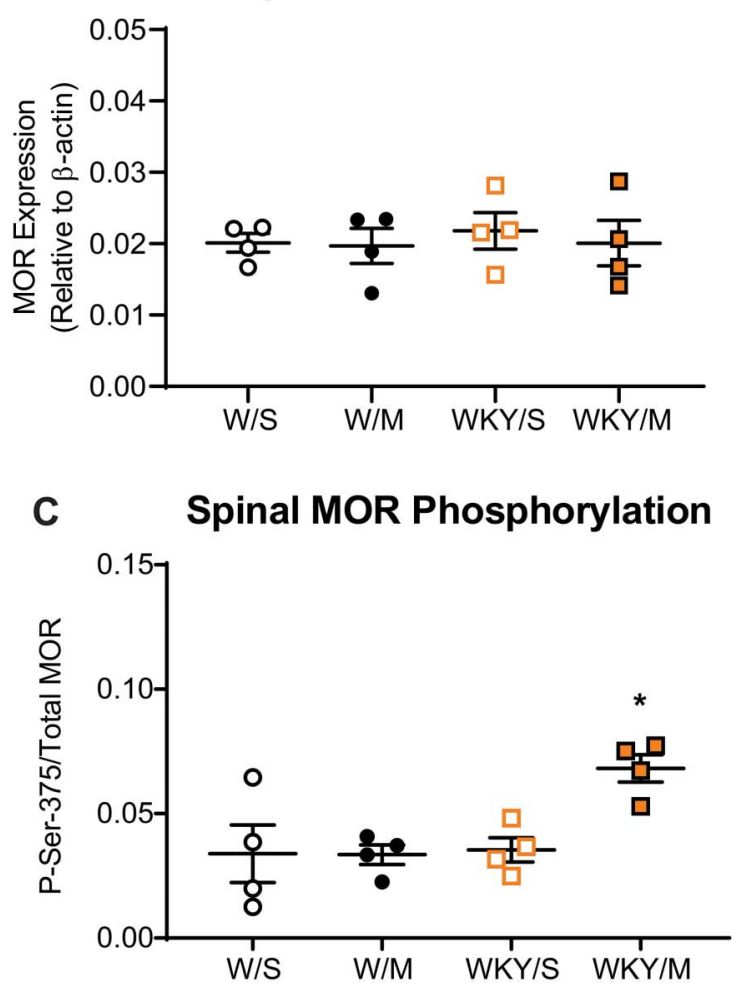

Figure 5. Altered P-ser375 in the spinal cord in the WKY or MIA model. Western blots of the expression of total MOR and P-ser375 in ipsilateral lumbar spinal cord homogenates (A). Densitometry quantification revealed consistent levels of total MOR (B) across strains and treatments $(n=4 /$ group) and in Pser375 in MIA-injected Wistar rats (C). There was a significant increase in the proportion of P-ser375MOR in MIA-injected WKY rats, compared with salineinjected controls. For expanded images of Western blots, see Supplemental Figure 6, available at http://links. Iww.com/PR9/A130). Bars represent median values and IQR, ${ }^{*} P=0.0312$, 2-way ANOVA with the Tukey post hoc multiple comparisons test (Supplemental Table 6, available at http://links.Iww.com/ PR9/A130). ANOVA, analysis of variance; MIA, monosodium iodoacetate; MOR, $\mu$-opioid receptors; WKY, Wistar Kyoto.

engagement of the endogenous opioidergic systems to counter increased pronociceptive signalling in models of chronic pain and align with evidence from clinical pain states. ${ }^{24,30,34}$ Unlike Wistar rats, both systemic naloxone or CTAP significantly lowered hind paw withdrawal thresholds in the absence of the model of OA pain in the WKY strain of rats, suggesting the endogenous opioidergic system is basally active in WKY rats in the absence of a pain state. In the presence of the model of OA pain in WKY rats, neither systemic naloxone nor CTAP had any additional effect on the hind paw withdrawal thresholds, suggesting in the presence of the model of OA pain, the endogenous opioidergic system is not further activated in WKY rats. One plausible explanation for this lack of chronic pain-induced engagement of the opioidergic inhibitory pathways in WKY rats is that the endogenous opioid system is already maximally activated in the absence of the pain state.

Increased levels of $\beta$-endorphin have previously been reported in the MIA model of OA pain in mice. ${ }^{2}$ In this article, baseline plasma levels of $\beta$-endorphin were significantly lower in WKY rats compared with Wistar rats; this difference was also observed after intra-articular injection of saline in the 2 strains of rats. These data do not neatly align with the effects of naloxone and CTAP, which suggest the presence of greater endogenous opioid tone in WKY rats in the absence of the OA pain model. This may point to a role of other endogenous opioid peptides; however, in our hands, plasma levels of enkephalin were below the limits of the detection assay and could not be tested. In the presence of established MIA-induced OA pain behaviour, only WKY rats had elevated levels of plasma $\beta$-endorphin, supporting a specific role in the model of high anxiety and OA pain behaviour. Nevertheless, contributions of other endogenous opioid peptides and the relationship between circulating and tissue-specific levels of opioids ${ }^{27}$ remain to be determined.

The spinal cord dorsal horn is a key signalling hub in pain pathways ${ }^{54}$ and a major site of action of both endogenous and exogenous opioids. ${ }^{18,59}$ Recordings of spinal cord dorsal horn WDR neurons in MIA-treated WKY rats compared with MIAtreated Wistar rats showed that the effects of systemic morphine on WDR responses to low-force and high-force mechanical stimulation of the hind paw were blunted in WKY MIA-treated rats. These effects may arise as a result of altered MOR function or exacerbated pronociceptive signalling due to inflammatory processes $^{29}$ or increased NMDA receptor signalling. ${ }^{36,52,60} \mathrm{We}$ hypothesised that these blunted inhibitory effects of exogenous morphine may arise, at least in part, due to desensitization or dysregulation of MOR.

The $\mathrm{C}$ terminus of MOR has a number of phosphorylation sites that contribute to receptor desensitization and internalization. Of the residues that undergo agonist-dependent phosphorylation, residues 375 to 379 (STANT) have a critical role in endogenous opioid-induced acute desensitization, recovery from desensitization, and internalization of MOR. ${ }^{4,32}$ Phosphorylation of the serine-375 residue of MOR was significantly elevated in the ipsilateral dorsal horn of the spinal cord of MIA-treated WKY rats, suggesting greater MOR tolerance in MIA-treated WKY rats. This may account, at least in part, for the loss of inhibitory effect of morphine under this condition. Nevertheless, we cannot discount changes in MOR expression or phosphorylation at other sites in the brain.

The limitations of our study include the use of an inbred rat strain to model anxiety-like behaviour. Differences in MOR gene expression between WKY and Sprague-Dawley rats have been reported for some brain regions. ${ }^{13}$ Despite no differences in MOR expression in the reward-associated nucleus accumbens, ${ }^{22}$ acquisition of morphine-induced conditioned place preference was reduced in WKY rats, supporting our evidence for dysfunctional responses to exogenous opioids in this strain. Alongside altered opioid function, WKY rats have lower basal levels of limbic serotonin and dopamine, resulting in a blunted response to acute stress, ${ }^{21}$ which is likely relevant to the clinical situation. Given the key roles for supraspinal monoamines in descending modulation of pain signalling, ${ }^{7}$ it is possible that both opioidergic and monoaminergic dysfunction contribute to augmented OA-like pain responses in WKY rats. Our study was only performed in male rats; although the relationship between anxiety and prescription opioid use for chronic pain is stronger in males than females, ${ }^{47}$ future work in female rats is important. Finally, although MOR internalization was not quantified here, increased 
MOR internalization in dorsal root ganglia has been demonstrated in a model of chronic inflammatory pain ${ }^{61}$ and shown to be further increased by morphine treatment.

Understanding why people with high anxiety and OA pain have higher opioid consumption is essential to develop alternative treatment strategies. Using a translationally relevant model, our data support a role of altered endogenous opioid receptor function and increased phosphorylation at serine residue 375 of MOR, which is required for morphinemediated desensitization, ${ }^{50}$ in the absence of previous exposure to exogenous opioid ligand. Our study highlights the functional impact of the combination of anxiety, chronic pain, and altered opioidergic tone, which leads not only to increased pain responses but also to decreased efficacy of opioid analgesia.

\section{Disclosures}

The authors have no conflicts of interest to declare.

\section{Acknowledgements}

The authors thank Rob Lane (University of Nottingham) for helpful discussions and advice on opioid receptor pharmacology. This work was supported by Arthritis Research United Kingdom (grants 18769, 20777) and MRC studentship (1653552). Author contributions: All authors were involved in drafting the article or revising it for important intellectual content, and all approved the final version. Study concept and design:

A. Lillywhite, S.G. Woodhams, S.V. Gonçalves,

L. Li, M. Canals, G.J. Hathway, and D.A. Walsh, VC. Data acquisition: A. Lillywhite, S.G. Woodhams, S.V. Gonçalves, D.J.G. Watson, L. Li, J.J. Burston, and P.R.W. Gowler. Data analysis: A. Lillywhite, S.G. Woodhams, S.V. Gonçalves, D.J.G. Watson, L. Li, J.J. Burston, P.R.W. Gowler, and V. Chapman. Manuscript: A. Lillywhite, S.G. Woodhams, S.V. Gonçalves, D.J.G. Watson, L. Li, J.J. Burston, P.R.W. Gowler, M. Canals, G.J. Hathway, D.A. Walsh, and V. Chapman.

\section{Appendix A. Supplemental digital content}

Supplemental digital content associated with this article can be found online at http://links.Iww.com/PR9/A130.

\section{Article history:}

Received 12 July 2021

Accepted 2 August 2021

\section{References}

[1] Abbruscato TJ, Thomas SA, Hruby VJ, Davis TP. Blood-brain barrier permeability and bioavailability of a highly potent and $\mu$-selective opioid receptor antagonist, CTAP: comparison with morphine. J Pharmacol Exp Ther 1997;280:402-9.

[2] Aman Y, Pitcher T, Ballard C, Malcangio M. Impaired chronic pain-like behaviour and altered opioidergic system in the TASTPM mouse model of Alzheimer's disease. Eur J Pain 2019;23:91-106.

[3] Arendt-Nielsen L, Skou ST, Nielsen TA, Petersen KK. Altered central sensitization and pain modulation in the CNS in chronic joint pain. Curr Osteoporos Rep 2015;13:225-34.

[4] Arttamangkul S, Leff ER, Koita O, Birdsong WT, Williams JT. Separation of acute desensitization and long-term tolerance of micro-opioid receptors is determined by the degree of C-terminal phosphorylation. Mol Pharmacol 2019;96:505-14.

[5] Axford J, Butt A, Heron C, Hammond J, Morgan J, Alavi A, Bolton J, Bland M. Prevalence of anxiety and depression in osteoarthritis: use of the
Hospital Anxiety and Depression Scale as a screening tool. Clin Rheumatol 2010;29:1277-83.

[6] Ballantyne JC. The brain on opioids. PAIN 2018;159(suppl 1):S24-s30.

[7] Bannister K, Dickenson AH. What do monoamines do in pain modulation? Curr Opin Support Palliat 2016;10:143-8.

[8] Barnett LA, Pritchard MG, Edwards JJ, Afolabi EK, Jordan KP, Healey EL, Finney AG, Chew-Graham CA, Mallen CD, Dziedzic KS. Relationship of anxiety with joint pain and its management: a population survey. Musculoskeletal Care 2018;16:353-62.

[9] Bartlett MJ, So LY, Szabò L, Skinner DP, Parent KL, Heien ML, Vanderah TW, Polt R, Sherman SJ, Falk T. Highly-selective $\mu$-opioid receptor antagonism does not block L-DOPA-induced dyskinesia in a rodent model. BMC Res Notes 2020;13:149.

[10] Bedson J, Chen Y, Hayward RA, Ashworth J, Walters K, Dunn KM, Jordan KP. Trends in long-term opioid prescribing in primary care patients with musculoskeletal conditions: an observational database study. PAIN 2016;157:1525-31.

[11] Bove SE, Calcaterra SL, Brooker RM, Huber CM, Guzman RE, Juneau PL, Schrier DJ, Kilgore KS. Weight bearing as a measure of disease progression and efficacy of anti-inflammatory compounds in a model of monosodium iodoacetate-induced osteoarthritis. Osteoarthr Cartilage 2003;11:821-30.

[12] Bruehl S, Burns JW, Gupta R, Buvanendran A, Chont M, Kinner E, Schuster E, Passik S, France CR. Endogenous opioid function mediates the association between laboratory-evoked pain sensitivity and morphine analgesic responses. PAIN 2013;154:1856-64.

[13] Burke NN, Ferdousi M, Deaver DR, Finn DP, Roche M, Kelly JP. Locomotor and anti-immobility effects of buprenorphine in combination with the opioid receptor modulator samidorphan in rats. Neuropharmacology 2019;146:327-36.

[14] Burns JW, Bruehl S, France CR, Schuster E, Orlowska D, Buvanendran A, Chont M, Gupta RK. Psychosocial factors predict opioid analgesia through endogenous opioid function. PAIN 2017;158:391-9.

[15] Burston JJ, Valdes AM, Woodhams SG, Mapp PI, Stocks J, Watson DJG, Gowler PRW, Xu L, Sagar DR, Fernandes G, Frowd N, Marshall L, Zhang W, Doherty M, Walsh DA, Chapman V. The impact of anxiety on chronic musculoskeletal pain and the role of astrocyte activation. PAIN 2019;160: 658-69.

[16] Chaplan SR, Bach FW, Pogrel JW, Chung JM, Yaksh TL. Quantitative assessment of tactile allodynia in the rat paw. J Neurosci Methods 1994; 53:55-63.

[17] Colvin LA, Bull F, Hales TG. Perioperative opioid analgesia-when is enough too much? A review of opioid-induced tolerance and hyperalgesia. Lancet 2019;393:1558-68.

[18] Corder G, Castro DC, Bruchas MR, Scherrer G. Endogenous and exogenous opioids in pain. Annu Rev Neurosci 2018;41:453-73.

[19] Curtis HJ, Croker R, Walker AJ, Richards GC, Quinlan J, Goldacre B. Opioid prescribing trends and geographical variation in England, 19982018: a retrospective database study. Lancet Psychiatry 2019;6:140-50.

[20] de Heer EW, Gerrits MM, Beekman AT, Dekker J, van Marwijk HW, de Waal MW, Spinhoven P, Penninx BW, van der Feltz-Cornelis CM. The association of depression and anxiety with pain: a study from NESDA. PLoS One 2014;9:e106907.

[21] De La Garza R, Mahoney JJ. A distinct neurochemical profile in WKY rats at baseline and in response to acute stress: implications for animal models of anxiety and depression. Brain Res 2004;1021:209-18.

[22] Dennis TS, Beck KD, Cominski TP, Bobzean SAM, Kuzhikandathil EV, Servatius RJ, Perrotti LI. Exposure to morphine-associated cues increases mu opioid receptor mRNA expression in the nucleus accumbens of Wistar Kyoto rats. Behav Brain Res 2016;313:208-13.

[23] Ferdousi MI, Calcagno P, Clarke M, Aggarwal S, Sanchez C, Smith KL, Eyerman DJ, Kelly JP, Roche M, Finn DP. Hyporesponsivity to mu-opioid receptor agonism in the Wistar-Kyoto rat model of altered nociceptive responding associated with negative affective state. PAIN 2021;162: 405-20.

[24] Fields H. State-dependent opioid control of pain. Nat Rev Neurosci 2004; 5:565-75.

[25] GBD_2013_DALYS_\&_HALE_Collaborators, Murray CJ, Barber RM, Foreman KJ, Abbasoglu Ozgoren A, Abd-Allah F, Abera SF, Aboyans V, Abraham JP, Abubakar I, Abu-Raddad LJ, Abu-Rmeileh NM, Achoki T, Ackerman IN, Ademi Z, Adou AK, Adsuar JC, Afshin A, Agardh EE, Alam SS, Alasfoor D, Albittar MI, Alegretti MA, Alemu ZA, Alfonso-Cristancho R, Alhabib S, Ali R, Alla F, Allebeck P, Almazroa MA, Alsharif U, Alvarez E, Alvis-Guzman N, Amare AT, Ameh EA, Amini H, Ammar W, Anderson HR, Anderson BO, Antonio CA, Anwari P, Arnlov J, Arsic Arsenijevic VS, Artaman A, Asghar RJ, Assadi R, Atkins LS, Avila MA, Awuah B, Bachman VF, Badawi A, Bahit MC, Balakrishnan K, Banerjee A, BarkerCollo SL, Barquera S, Barregard L, Barrero LH, Basu A, Basu S, 
Basulaiman MO, Beardsley J, Bedi N, Beghi E, Bekele T, Bell ML, Benjet $\mathrm{C}$, Bennett DA, Bensenor IM, Benzian H, Bernabe E, Bertozzi-Villa A, Beyene TJ, Bhala N, Bhalla A, Bhutta ZA, Bienhoff K, Bikbov B, Biryukov S, Blore JD, Blosser CD, Blyth FM, Bohensky MA, Bolliger IW, Bora Basara B, Bornstein NM, Bose D, Boufous S, Bourne RR, Boyers LN, Brainin M, Brayne CE, Brazinova A, Breitborde NJ, Brenner H, Briggs AD, Brooks PM, Brown JC, Brugha TS, Buchbinder R, Buckle GC, Budke $\mathrm{CM}$, Bulchis A, Bulloch AG, Campos-Nonato IR, Carabin H, Carapetis JR, Cardenas R, Carpenter DO, Caso V, Castaneda-Orjuela CA, Castro RE, Catala-Lopez F, Cavalleri F, Cavlin A, Chadha VK, Chang JC, Charlson FJ, Chen H, Chen W, Chiang PP, Chimed-Ochir O, Chowdhury R, Christensen H, Christophi CA, Cirillo M, Coates MM, Coffeng LE, Coggeshall MS, Colistro V, Colquhoun SM, Cooke GS, Cooper C, Cooper LT, Coppola LM, Cortinovis M, Criqui MH, Crump JA, CuevasNasu L, Danawi H, Dandona L, Dandona R, Dansereau E, Dargan PI, Davey G, Davis A, Davitoiu DV, Dayama A, De Leo D, Degenhardt L, Del Pozo-Cruz B, Dellavalle RP, Deribe K, Derrett $S$, Des Jarlais DC, Dessalegn M, Dharmaratne SD, Dherani MK, Diaz-Torne C, Dicker D, Ding EL, Dokova K, Dorsey ER, Driscoll TR, Duan L, Duber HC, Ebel BE, Edmond KM, Elshrek YM, Endres M, Ermakov SP, Erskine HE, Eshrati B, Esteghamati A, Estep K, Faraon EJ, Farzadfar F, Fay DF, Feigin VL, Felson DT, Fereshtehnejad SM, Fernandes JG, Ferrari AJ, Fitzmaurice C, Flaxman AD, Fleming TD, Foigt N, Forouzanfar MH, Fowkes FG, Paleo UF, Franklin RC, Furst T, Gabbe B, Gaffikin L, Gankpe FG, Geleijnse JM, Gessner BD, Gething P, Gibney KB, Giroud M, Giussani G, Gomez Dantes H, Gona P, Gonzalez-Medina D, Gosselin RA, Gotay CC, Goto A, Gouda HN, Graetz N, Gugnani HC, Gupta R, Gupta R, Gutierrez RA, Haagsma J, Hafezi-Nejad N, Hagan H, Halasa YA, Hamadeh RR, Hamavid H, Hammami M, Hancock J, Hankey GJ, Hansen GM, Hao Y, Harb HL, Haro JM, Havmoeller R, Hay SI, Hay RJ, Heredia-Pi IB, Heuton KR, Heydarpour P, Higashi H, Hijar M, Hoek HW, Hoffman HJ, Hosgood HD, Hossain M, Hotez PJ, Hoy DG, Hsairi M, Hu G, Huang C, Huang JJ, Husseini A, Huynh C, lannarone ML, Iburg KM, Innos K, Inoue M, Islami F, Jacobsen $\mathrm{KH}$, Jarvis DL, Jassal SK, Jee SH, Jeemon P, Jensen PN, Jha V, Jiang $G$, Jiang $Y$, Jonas JB, Juel $K$, Kan $H$, Karch A, Karema CK, Karimkhani C, Karthikeyan G, Kassebaum NJ, Kaul A, Kawakami N, Kazanjan K, Kemp AH, Kengne AP, Keren A, Khader YS, Khalifa SE, Khan EA, Khan G, Khang YH, Kieling C, Kim D, Kim S, Kim Y, Kinfu Y, Kinge JM, Kivipelto M, Knibbs LD, Knudsen AK, Kokubo Y, Kosen S, Krishnaswami S, Kuate Defo B, Kucuk Bicer B, Kuipers EJ, Kulkarni C, Kulkarni VS, Kumar GA, Kyu HH, Lai T, Lalloo R, Lallukka T, Lam H, Lan Q, Lansingh VC, Larsson A, Lawrynowicz AE, Leasher JL, Leigh J, Leung R, Levitz CE, Li B, Li Y, Li Y, Lim SS, Lind M, Lipshultz SE, Liu S, Liu Y, Lloyd BK, Lofgren $\mathrm{KT}$, Logroscino G, Looker KJ, Lortet-Tieulent J, Lotufo PA, Lozano R, Lucas RM, Lunevicius R, Lyons RA, Ma S, Macintyre MF, Mackay MT, Majdan M, Malekzadeh R, Marcenes W, Margolis DJ, Margono C, Marzan MB, Masci JR, Mashal MT, Matzopoulos R, Mayosi BM, Mazorodze TT, McGill NW, McGrath JJ, McKee M, McLain A, Meaney PA, Medina C, Mehndiratta MM, Mekonnen W, Melaku YA, Meltzer M, Memish ZA, Mensah GA, Meretoja A, Mhimbira FA, Micha R, Miller TR, Mills EJ, Mitchell PB, Mock CN, Mohamed Ibrahim N, Mohammad KA, Mokdad AH, Mola GL, Monasta L, Montanez Hernandez JC, Montico M, Montine TJ, Mooney MD, Moore AR, Moradi-Lakeh M, Moran AE, Mori R, Moschandreas J, Moturi WN, Moyer ML, Mozaffarian D, Msemburi WT, Mueller UO, Mukaigawara M, Mullany EC, Murdoch ME, Murray J, Murthy KS, Naghavi M, Naheed A, Naidoo KS, Naldi L, Nand D, Nangia V, Narayan KM, Nejjari C, Neupane SP, Newton CR, Ng M, Ngalesoni FN, Nguyen G, Nisar MI, Nolte S, Norheim OF, Norman RE, Norrving B, Nyakarahuka L, Oh IH, Ohkubo T, Ohno SL, Olusanya BO, Opio JN, Ortblad K, Ortiz A, Pain AW, Pandian JD, Panelo Cl, Papachristou C, Park EK, Park JH, Patten SB, Patton GC, Paul VK, Pavlin BI, Pearce N, Pereira DM, Perez-Padilla R, Perez-Ruiz F, Perico N, Pervaiz A, Pesudovs K, Peterson CB, Petzold M, Phillips MR, Phillips BK, Phillips DE, Piel FB, Plass D, Poenaru D, Polinder S, Pope D, Popova S, Poulton RG, Pourmalek F, Prabhakaran D, Prasad NM, Pullan RL, Qato DM, Quistberg DA, Rafay A, Rahimi K, Rahman SU, Raju M, Rana SM, Razavi H, Reddy KS, Refaat A, Remuzzi G, Resnikoff S, Ribeiro AL, Richardson L, Richardus JH, Roberts DA, Rojas-Rueda D, Ronfani L, Roth GA, Rothenbacher D, Rothstein DH, Rowley JT, Roy N, Ruhago GM, Saeedi MY, Saha S, Sahraian MA, Sampson UK, Sanabria JR, Sandar L, Santos IS, Satpathy M, Sawhney M, Scarborough P, Schneider IJ, Schottker B, Schumacher AE, Schwebel DC, Scott JG, Seedat S, Sepanlou SG, Serina PT, Servan-Mori EE, Shackelford KA, Shaheen A, Shahraz S, Shamah Levy T, Shangguan S, She J, Sheikhbahaei S, Shi P, Shibuya K, Shinohara Y, Shiri R, Shishani K, Shiue I, Shrime MG, Sigfusdottir ID, Silberberg DH, Simard EP, Sindi S, Singh A, Singh JA, Singh L, Skirbekk V, Slepak EL, Sliwa K, Soneji S, Soreide K, Soshnikov S, Sposato LA, Sreeramareddy CT, Stanaway JD, Stathopoulou V, Stein
DJ, Stein MB, Steiner C, Steiner TJ, Stevens A, Stewart A, Stovner LJ, Stroumpoulis K, Sunguya BF, Swaminathan S, Swaroop M, Sykes BL, Tabb KM, Takahashi K, Tandon N, Tanne D, Tanner M, Tavakkoli M, Taylor HR, Te Ao BJ, Tediosi F, Temesgen AM, Templin T, Ten Have M, Tenkorang EY, Terkawi AS, Thomson B, Thorne-Lyman AL, Thrift AG, Thurston GD, Tillmann T, Tonelli M, Topouzis F, Toyoshima H, Traebert J, Tran BX, Trillini M, Truelsen T, Tsilimbaris M, Tuzcu EM, Uchendu US, Ukwaja KN, Undurraga EA, Uzun SB, Van Brakel WH, Van De Vijver S, van Gool CH, Van Os J, Vasankari TJ, Venketasubramanian N, Violante FS, Vlassov W, Vollset SE, Wagner GR, Wagner J, Waller SG, Wan X, Wang $H$, Wang J, Wang L, Warouw TS, Weichenthal S, Weiderpass E, Weintraub RG, Wenzhi W, Werdecker A, Westerman R, Whiteford HA, Wilkinson JD, Williams TN, Wolfe CD, Wolock TM, Woolf AD, Wulf $S$, Wurtz B, Xu G, Yan LL, Yano Y, Ye P, Yentur GK, Yip P, Yonemoto N, Yoon SJ, Younis MZ, Yu C, Zaki ME, Zhao Y, Zheng Y, Zonies D, Zou X, Salomon JA, Lopez AD, Vos T. Global, regional, and national disabilityadjusted life years (DALYs) for 306 diseases and injuries and healthy life expectancy (HALE) for 188 countries, 1990-2013: quantifying the epidemiological transition. Lancet 2015;386:2145-91.

[26] Glyn-Jones S, Palmer AJ, Agricola R, Price AJ, Vincent TL, Weinans H, Carr AJ. Osteoarthritis. Lancet 2015;386:376-87.

[27] Gudehithlu KP, Tehwani GA, Bhargava HN. $\beta$-endorphin and methionineenkephalin levels in discrete brain regions, spinal cord, pituitary gland and plasma of morphine tolerant-dependent and abstinent rats. Brain Res 1991;553:284-90.

[28] Guingamp C, Gegout-Pottie P, Philippe L, Terlain B, Netter P, Gillet P. Mono-iodoacetate-induced experimental osteoarthritis: a doseresponse study of loss of mobility, morphology, and biochemistry. Arthritis Rheum 1997;40:1670-9.

[29] Ji RR, Nackley A, Huh Y, Terrando N, Maixner W. Neuroinflammation and central sensitization in chronic and widespread pain. Anesthesiology 2018;129:343-66.

[30] Kayser V, Guilbaud G. Differential effects of various doses of morphine and naloxone on two nociceptive test thresholds in arthritic and normal rats. PAIN 1990;41:353-63.

[31] Kilkenny C, Browne WJ, Cuthi I, Emerson M, Altman DG. Improving bioscience research reporting: the ARRIVE guidelines for reporting animal research. Vet Clin Pathol 2012;41:27-31.

[32] Kliewer A, Schmiedel F, Sianati S, Bailey A, Bateman JT, Levitt ES, Williams JT, Christie MJ, Schulz S. Phosphorylation-deficient G-proteinbiased mu-opioid receptors improve analgesia and diminish tolerance but worsen opioid side effects. Nat Commun 2019;10:367.

[33] Krebs EE, Gravely A, Nugent S, Jensen AC, DeRonne B, Goldsmith ES, Kroenke K, Bair MJ, Noorbaloochi S. Effect of opioid vs nonopioid medications on pain-related function in patients with chronic back pain or hip or knee osteoarthritis pain: the SPACE randomized clinical trial. JAMA 2018;319:872-82.

[34] Levine JD, Gordon NC, Jones RT, Fields HL. The narcotic antagonist naloxone enhances clinical pain. Nature 1978;272:826-7.

[35] Li J, Simone DA, Larson AA. Windup leads to characteristics of central sensitization. PAIN 1999;79:75-82.

[36] Li X-H, Miao H-H, Zhuo M. NMDA receptor dependent long-term potentiation in chronic pain. Neurochem 2019;44:531-8.

[37] Markowitz R, Jacobson J, Bain G, Kornetsky C. Naloxone blockade of morphine analgesia: a dose-effect study of duration and magnitude. J Pharmacol Exp Ther 1976;199:385-8.

[38] McAuley JD, Stewart AL, Webber ES, Cromwell HC, Servatius RJ, Pang $\mathrm{KCH}$. Wistar-Kyoto rats as an animal model of anxiety vulnerability: support for a hypervigilance hypothesis. Behav Brain Res 2009;204:162-8.

[39] McMahon SB. Wall and Melzack's textbook of pain. Philadelphia, PA: Elsevier/Saunders, 2013.

[40] Mills C, LeBlond D, Joshi S, Zhu C, Hsieh G, Jacobson P, Meyer M, Decker M. Estimating efficacy and drug ED50's using von Frey thresholds: impact of weber's law and log transformation. The $J$ Pain 2012;13:519-23.

[41] Namba RS, Singh A, Paxton EW, Inacio MCS. Patient factors associated with prolonged postoperative opioid use after total knee arthroplasty. J Arthroplasty 2018;33:2449-54.

[42] Pasternak GW. Preclinical pharmacology and opioid combinations. Pain Med (Malden, MA) 2012;13(suppl 1):S4-S11.

[43] Pasternak GW. Opiate pharmacology and relief of pain. J Clin Oncol 2014;32:1655-61

[44] Perrot S. Osteoarthritis pain. Best Pract Res Clin Rheumatol 2015;29: 90-7.

[45] Petraschka M, Li S, Gillbert TL, Westenbroek RE, Bruchas MR, Schreiber S, Lowe J, Low MJ, Pintar JE, Chavkin C. The absence of endogenous $\beta$-endorphin selectively blocks phosphorylation and desensitization of 
mu opioid receptors following partial sciatic nerve ligation. Neuroscience 2007;146:1795-807.

[46] Pezze M, McGarrity S, Mason R, Fone KC, Bast T. Too little and too much: hypoactivation and disinhibition of medial prefrontal cortex cause attentional deficits. J Neurosci 2014;34:7931-46.

[47] Rogers AH, Manning K, Garey L, Smit T, Zvolensky MJ. Sex differences in the relationship between anxiety sensitivity and opioid misuse among adults with chronic pain. Addict Behav 2020;102:106156.

[48] Sagar DR, Staniaszek LE, Okine BN, Woodhams S, Norris LM, Pearson RG, Garle MJ, Alexander SPH, Bennett AJ, Barrett DA, Kendall DA, Scammell BE, Chapman V. Tonic modulation of spinal hyperexcitability by the endocannabinoid receptor system in a rat model of osteoarthritis pain. Arthritis Rheum 2010;62:3666-76.

[49] Schött E, Berge OG, Ängeby-Möller K, Hammarström G, Dalsgaard CJ, Brodin E. Weight bearing as an objective measure of arthritic pain in the rat. J Pharmacol Toxicol Methods 1994;31:79-83.

[50] Schulz S, Mayer D, Pfeiffer M, Stumm R, Koch T, Höllt V. Morphine induces terminal $\mu$-opioid receptor desensitization by sustained phosphorylation of serine-375. EMBO J 2004;23:3282-9.

[51] Suokas AK, Walsh DA, McWilliams DF, Condon L, Moreton B, Wylde V, Arendt-Nielsen L, Zhang W. Quantitative sensory testing in painful osteoarthritis: a systematic review and meta-analysis. Osteoarthr Cartilage 2012;20:1075-85.

[52] Taylor BK, Corder G. Endogenous analgesia, dependence, and latent pain sensitization. In: Taylor BK, Finn DP, eds. Behavioral Neurobiology of Chronic Pain. Berlin, Heidelberg: Springer Berlin Heidelberg, 2014; 283-325.

[53] Thorlund JB, Turkiewicz A, Prieto-Alhambra D, Englund M. Opioid use in knee or hip osteoarthritis: a region-wide population-based cohort study. Osteoarthr Cartilage 2019;27:871-7.

[54] Todd AJ. Neuronal circuitry for pain processing in the dorsal horn. Nat Rev Neurosci 2010;11:823-36.

[55] Urch CE, Dickenson AH. In vivo single unit extracellular recordings from spinal cord neurones of rats. Brain Res Brain Res Protoc 2003;12:26-34.

[56] Valdes AM, Warner SC, Harvey HL, Fernandes GS, Doherty S, Jenkins W, Wheeler M, Doherty M. Use of prescription analgesic medication and pain catastrophizing after total joint replacement surgery. Semin Arthritis Rheum 2015;45:150-5.

[57] Vos T, Flaxman AD, Naghavi M, Lozano R, Michaud C, Ezzati M, Shibuya K, Salomon JA, Abdalla S, Aboyans V, Abraham J, Ackerman I, Aggarwal R, Ahn SY, Ali MK, Alvarado M, Anderson HR, Anderson LM, Andrews KG, Atkinson C, Baddour LM, Bahalim AN, Barker-Collo S, Barrero LH, Bartels DH, Basanez MG, Baxter A, Bell ML, Benjamin EJ, Bennett D, Bernabe E, Bhalla K, Bhandari B, Bikbov B, Bin Abdulhak A, Birbeck G, Black JA, Blencowe $H$, Blore JD, Blyth F, Bolliger I, Bonaventure A, Boufous S, Bourne R, Boussinesq M, Braithwaite T, Brayne C, Bridgett L, Brooker S, Brooks P, Brugha TS, Bryan-Hancock C, Bucello C, Buchbinder R, Buckle G, Budke CM, Burch M, Burney P, Burstein R, Calabria B, Campbell B, Canter CE, Carabin H, Carapetis J, Carmona L, Cella C, Charlson F, Chen H, Cheng AT, Chou D, Chugh SS, Coffeng LE, Colan SD, Colquhoun S, Colson KE, Condon J, Connor MD, Cooper LT, Corriere M, Cortinovis M, de Vaccaro KC, Couser W, Cowie BC, Criqui $\mathrm{MH}$, Cross M, Dabhadkar KC, Dahiya M, Dahodwala N, Damsere-Derry J, Danaei G, Davis A, De Leo D, Degenhardt L, Dellavalle R, Delossantos A, Denenberg J, Derrett S, Des Jarlais DC, Dharmaratne SD, Dherani M, Diaz-Torne C, Dolk H, Dorsey ER, Driscoll T, Duber H, Ebel B, Edmond K,
Elbaz A, Ali SE, Erskine H, Erwin PJ, Espindola P, Ewoigbokhan SE, Farzadfar F, Feigin V, Felson DT, Ferrari A, Ferri CP, Fevre EM, Finucane MM, Flaxman S, Flood L, Foreman K, Forouzanfar MH, Fowkes FG, Franklin R, Fransen M, Freeman MK, Gabbe BJ, Gabriel SE, Gakidou E, Ganatra HA, Garcia B, Gaspari F, Gillum RF, Gmel G, Gosselin R, Grainger R, Groeger J, Guillemin F, Gunnell D, Gupta R, Haagsma J, Hagan H, Halasa YA, Hall W, Haring D, Haro JM, Harrison JE, Havmoeller R, Hay RJ, Higashi H, Hill C, Hoen B, Hoffman H, Hotez PJ, Hoy D, Huang JJ, Ibeanusi SE, Jacobsen $\mathrm{KH}$, James SL, Jarvis $D$, Jasrasaria $R$, Jayaraman S, Johns N, Jonas JB, Karthikeyan G, Kassebaum N, Kawakami N, Keren A, Khoo JP, King CH, Knowlton LM, Kobusingye O, Koranteng A, Krishnamurthi R, Lalloo R, Laslett LL, Lathlean T, Leasher JL, Lee YY, Leigh J, Lim SS, Limb E, Lin JK, Lipnick M, Lipshultz SE, Liu W, Loane M, Ohno SL, Lyons R, Ma J, Mabweijano J, Macintyre MF, Malekzadeh R, Mallinger L, Manivannan S, Marcenes W, March L, Margolis DJ, Marks GB, Marks R, Matsumori A, Matzopoulos R, Mayosi BM, McAnulty JH, McDermott MM, McGill N, McGrath J, Medina-Mora ME, Meltzer M, Mensah GA, Merriman TR, Meyer AC, Miglioli V, Miller M, Miller TR, Mitchell PB, Mocumbi AO, Moffitt TE, Mokdad AA, Monasta L, Montico M, Moradi-Lakeh M, Moran A, Morawska L, Mori R, Murdoch ME, Mwaniki MK, Naidoo K, Nair MN, Naldi L, Narayan KM, Nelson PK, Nelson RG, Nevitt MC, Newton CR, Nolte S, Norman P, Norman R, O'Donnell M, O'Hanlon S, Olives C, Omer SB, Ortblad K, Osborne R, Ozgediz D, Page A, Pahari B, Pandian JD, Rivero AP, Patten SB, Pearce N, Padilla RP, Perez-Ruiz F, Perico N, Pesudovs K, Phillips D, Phillips MR, Pierce K, Pion S, Polanczyk GV, Polinder S, Pope CA III, Popova S, Porrini E, Pourmalek F, Prince M, Pullan RL, Ramaiah KD, Ranganathan D, Razavi H, Regan M, Rehm JT, Rein DB, Remuzzi G, Richardson K, Rivara FP, Roberts T, Robinson C, De Leon FR, Ronfani L, Room R, Rosenfeld LC, Rushton L, Sacco RL, Saha S, Sampson U, Sanchez-Riera L, Sanman E, Schwebel DC, Scott JG, Segui-Gomez M, Shahraz S, Shepard DS, Shin H, Shivakoti R, Singh D, Singh GM, Singh JA, Singleton J, Sleet DA, Sliwa K, Smith E, Smith JL, Stapelberg NJ, Steer A, Steiner T, Stolk WA, Stovner LJ, Sudfeld C, Syed S, Tamburlini G, Tavakkoli M, Taylor HR, Taylor JA, Taylor WJ, Thomas B, Thomson WM, Thurston GD, Tleyjeh IM, Tonelli M, Towbin JA, Truelsen T, Tsilimbaris MK, Ubeda C, Undurraga EA, van der Werf $\mathrm{MJ}$, van Os J, Vavilala MS, Venketasubramanian $\mathrm{N}$, Wang $\mathrm{M}$, Wang $\mathrm{W}$, Watt $\mathrm{K}$, Weatherall DJ, Weinstock MA, Weintraub R, Weisskopf MG, Weissman MM, White RA, Whiteford $\mathrm{H}$, Wiersma ST, Wilkinson JD, Williams HC, Williams SR, Witt E, Wolfe F, Woolf AD, Wulf S, Yeh PH, Zaidi AK, Zheng ZJ, Zonies D, Lopez AD, Murray CJ, AlMazroa MA, Memish ZA. Years lived with disability (YLDs) for 1160 sequelae of 289 diseases and injuries 1990-2010: a systematic analysis for the Global Burden of Disease Study 2010. Lancet 2012;380:2163-96.

[58] Walf AA, Frye CA. The use of the elevated plus maze as an assay of anxiety-related behavior in rodents. Nat Protoc 2007;2:322-8.

[59] Yaksh TL. Pharmacology and mechanisms of opioid analgesic activity. Acta Anaesthesiol Scand 1997;41:94-111.

[60] Zhuo M. Ionotropic glutamate receptors contribute to pain transmission and chronic pain. Neuropharmacology 2017;112:228-34.

[61] Zöllner C, Mousa SA, Fischer O, Rittner HL, Shaqura M, Brack A, Shakibaei M, Binder W, Urban F, Stein C, Schäfer M. Chronic morphine use does not induce peripheral tolerance in a rat model of inflammatory pain. J Clin Investig 2008;118:1065-73. 